\title{
Perihilar Bile Duct Cancer TNM Finding v8
}

National Cancer Institute

\section{Source}

National Cancer Institute. Perihilar Bile Duct Cancer TNM Finding v8. NCI Thesaurus.

Code 134712.

A finding about one or more characteristics of perihilar bile duct cancer, following the rules of the TNM AJCC V8 classification system. This staging system applies to perihilar cholangiocarcinomas. Well-differentiated neuroendocrine tumors and sarcomas are not staged using this staging system. (from AJCC 8th Ed.) 